Iran Journal of Nursing (IJN)

Vol 32, No. 117, Apr 2019: 69- 79

\title{
The Association of the Quality of Work Life and General Health of the Nurses in Psychiatric Wards
}

\author{
Leila Esmaeilpour ${ }^{1}, *$ Ezzat Jafarjalal ${ }^{2}$
}

\begin{abstract}
Background \& Aims: The level of tension and stress is comparatively higher in psychiatric units due to the nature of the disorders and conditions of the patients under treatment, which could threaten various aspects of the general health of psychiatric nurses. Furthermore, this issue could adversely affect the quality of work life in nurses. The present study aimed to investigate the association between the quality of work life and general health of the nurses in the psychiatric wards of the teaching hospitals affiliated to the medical universities in Tehran, Iran.

Materials \& Methods: This descriptive-correlational study was conducted on 200 nurses engaged in the psychiatric wards of the teaching hospitals affiliated to the medical universities in Tehran. The participants were selected via stratified random sampling. Data were collected using the quality of work life questionnaire and general health questionnaire. Data analysis was performed in SPSS version 20 using descriptive and inferential statistics, including Pearson's correlation-coefficient, independent t-test, and the analysis of variance (ANOVA). Results: The mean scores of the quality of work life and general health of the nurses were moderate and favorable, respectively. Significant inverse correlations were observed between the quality of work life and general health in the dimensions of anxiety and sleep disorders $(\mathrm{P}=0.026)$ and depressive symptoms $(\mathrm{P}=0.041)$, so that the increased quality of work life could reduce the scores of these dimensions of general health.

Conclusion: According to the results, the quality of work life could affect the general health of psychiatric nurses in terms of anxiety, depressive symptoms, and sleep disorders. Therefore, the adoption of effective policies to improve the quality of work life could positively influence the general health of the nurses employed in psychiatric wards.
\end{abstract}

Keywords: Quality of Work Life, General Health, Nurse, Psychiatric Ward

\section{Conflict of Interest: No}

How to Cite: Esmaeilpour L, Jafarjalal E. The Association of the Quality of Work Life and General Health of the Nurses in Psychiatric Wards. Iran Journal of Nursing. 2019; 32(117):69-79.

Received: 19 Jan 2019

Accepted: 20 Apr 2019

\footnotetext{
1. MS in Psychiatric Nursing, School of Nursing and Midwifery, Iran University of Medical Sciences, Tehran, Iran 2. Lecturer, Department of Nursing Management, School of Nursing and Midwifery, Iran University of Medical Sciences, Tehran, Iran. (*Corresponding author) 


\title{
ارتباط كيفيت زندكى كارى با سلامت عمومى بر ستاران شاغل در بخش هاى روانيزشكى
}

\author{
ليلا اسماعيل بور '، "عزت جعفرجلال'
}

\begin{abstract}
جكيده
زمينه و هدف: با توجه به ماهيت بيمارى و وضعيت مددجويانى كه تحت درمان هستند، در بخشهاى روانيزشكى فشار، تنش و استرس بيشتر از ساير

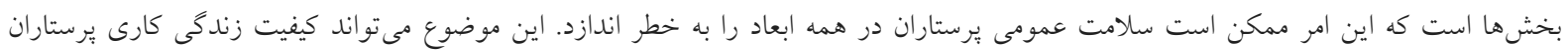

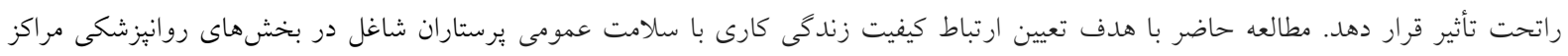

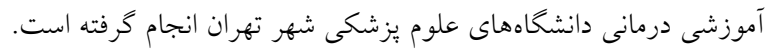

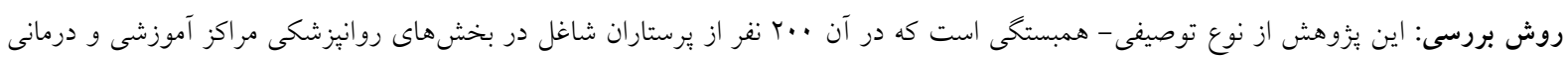

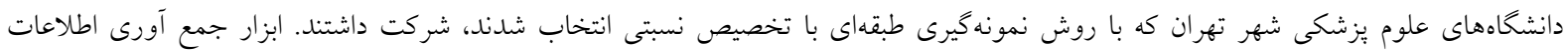
شامل General Health Questionnaire و بود. در تجزيه و تحليل آمارى از روشهاى آمار آنار

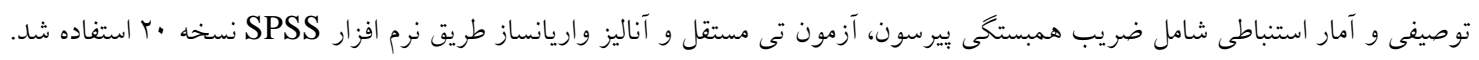

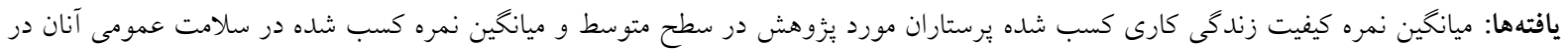

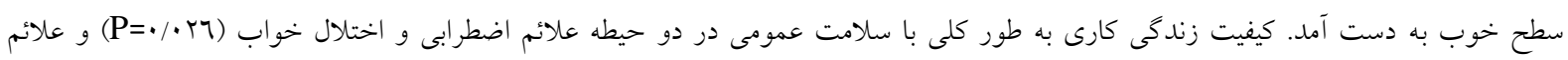

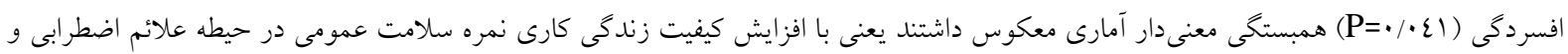

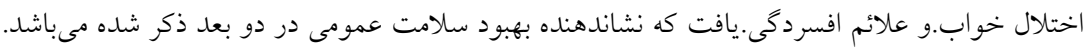

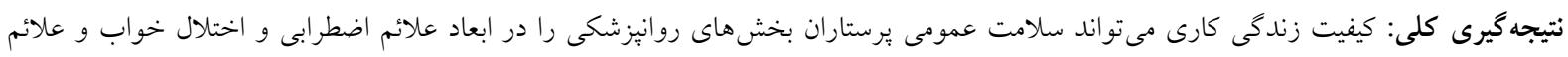

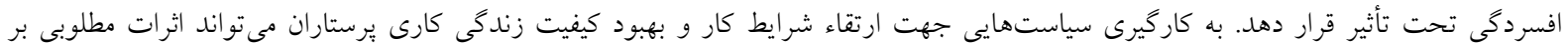
سلامت عمومى آنان در بخش هاى روانيز تشكى داشته باشد.

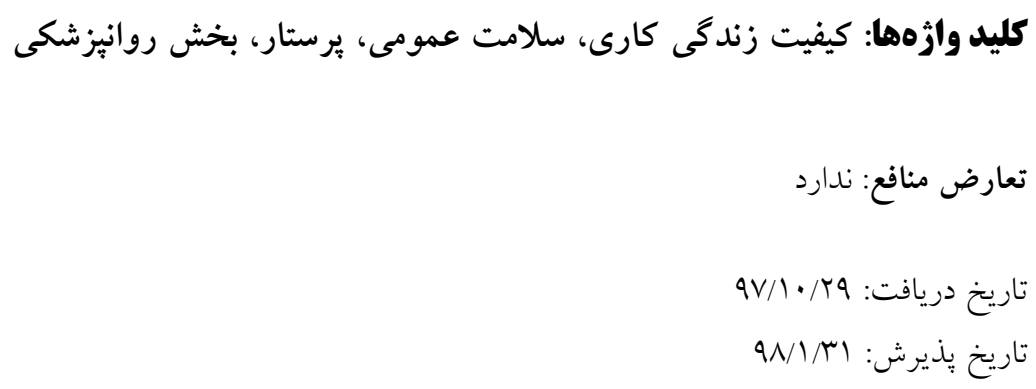

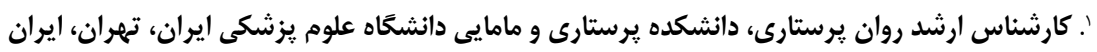

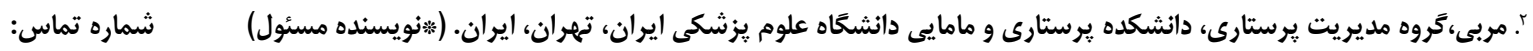
Email: Jafarjalal.e@iums.ac.ir $+q 1 r \mu q+V+\varepsilon \tau$ 
شده است. همجنين علاوه بر وجود مشكلات در بعد

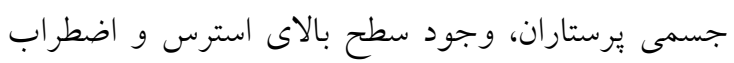

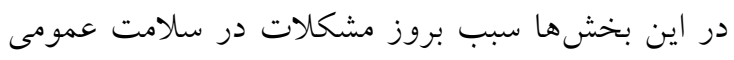
يرستاران در جنبههاى روانى و اجتماعى نيز شده است (7).

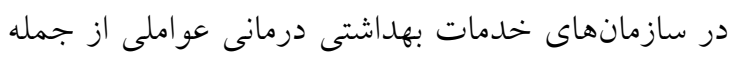
خشونت در محل كار يكى امر اجتناب نايذير است كه بعد

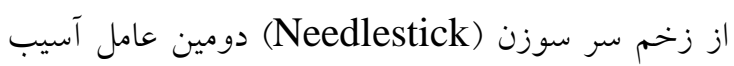

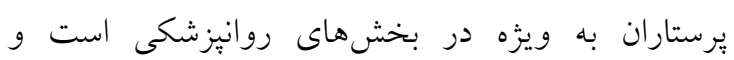

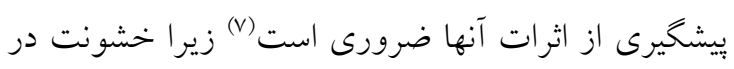

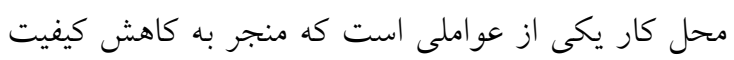

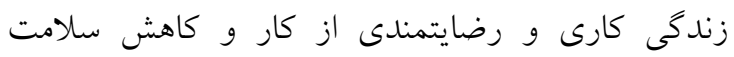

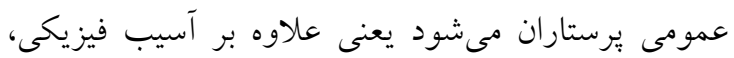

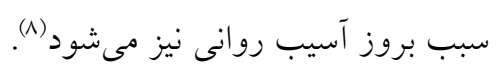

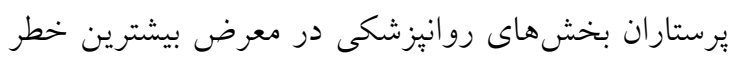

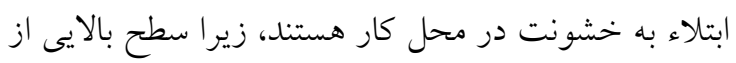

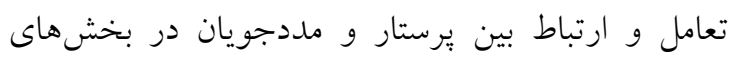

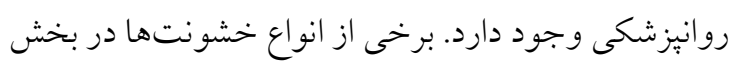

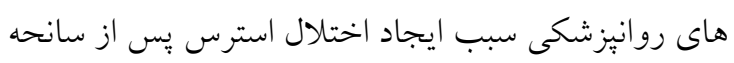

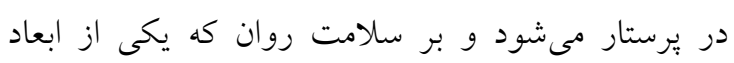

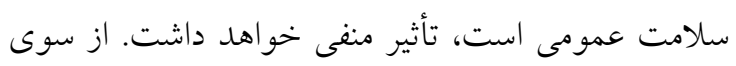

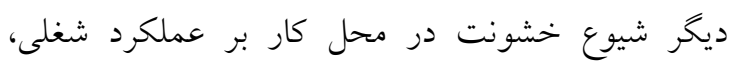

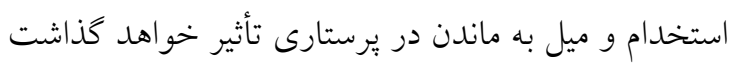
و سبب خستخى روانى و احساس نا اميدى در رابطه با نابن

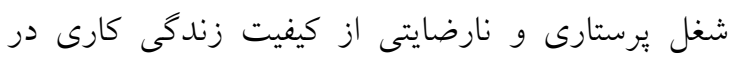
يرستاران شاغل در بخشهاى روانيزشكى مى شود (9). علاوه بر خشونت در محل كار عواملى ديكرى از جمله

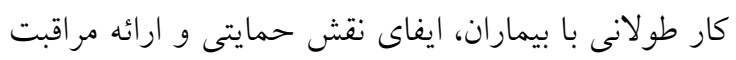

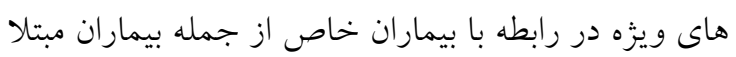

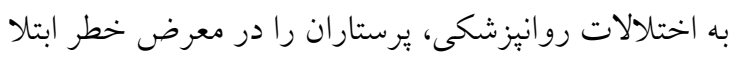

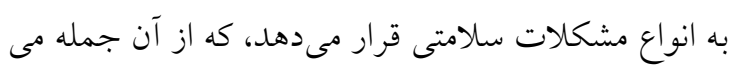

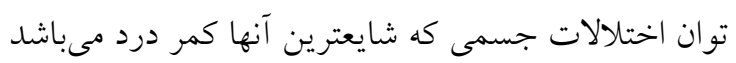

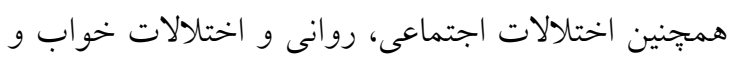
ريتمهاى بيولوزيك را نام برد (•).
مقدمه

يرستاران بزركترين كروه حرفهاى در سيستم مراقبت بهداشتى و درمانى هستند و نقش كليدى در فراهم كردن

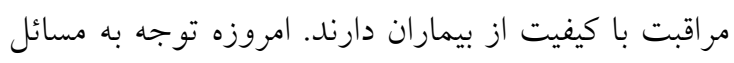
مرتبط با كيفيت زندكى كارى و سلامت عمومى برستاران

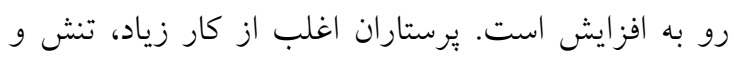
استرس شغلى، خستكى و نبود اوقات فراغت كافى شكايت

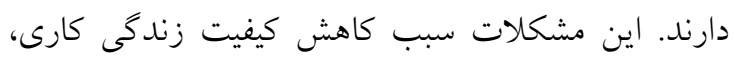

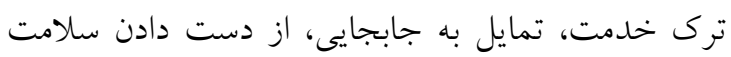

جسمى و روانى و اجتماعى در برستاران شده است (1).

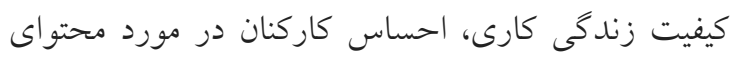
شغلى، محيط كار فيزيكى، يرداختها، مزايا، تبليغات،

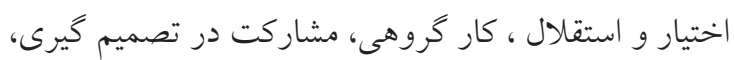

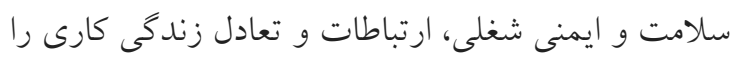

$$
\text { يوشش مى شهد (r). }
$$

نارضايتى از كيفيت زندكى كارى موضوعى است كه تقريباً

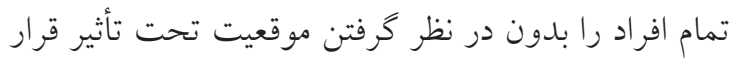
مىدهد و جدا سازى و شناسايى تمام مواردى كه بر كيفيت

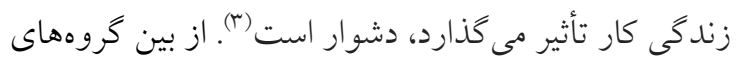

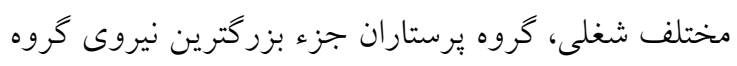

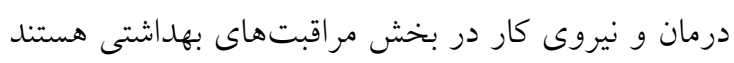

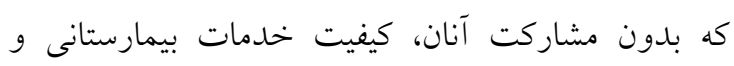

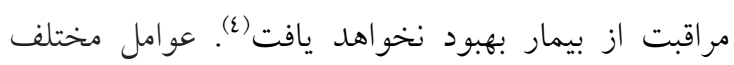

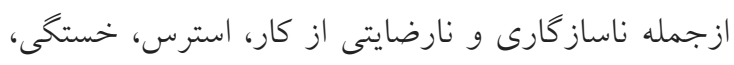

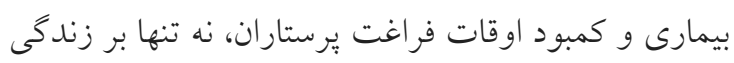

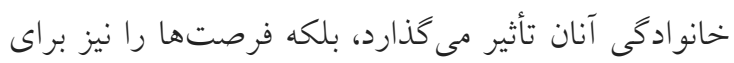
يمشرفت حرفهاى از آنان سلب مى كند (0).

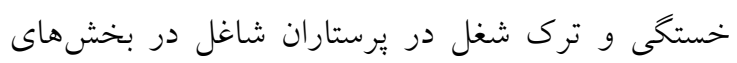

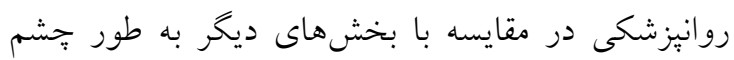

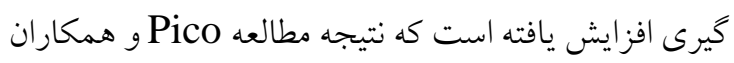

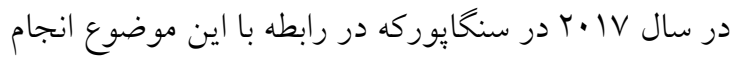

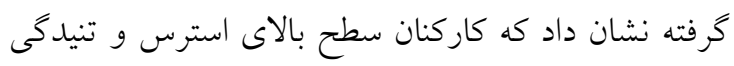
را تجربه مى كنند كه سبب كاهش كارايى، خستخى و خروج از كار برستاران و كاهش سطح كيفيت زندكى كارى آنها 
بيشتر ابعاد زندگى كار خود شكايت دارند (V). همجنين در

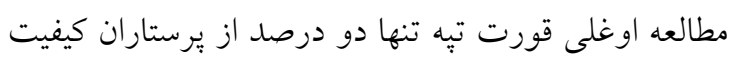

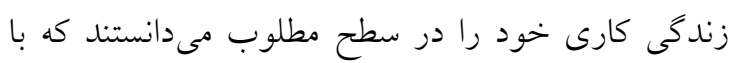

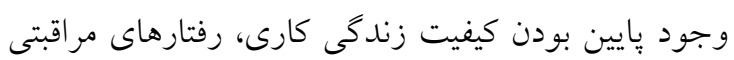
خود را در سطح مطلوب ارائه مى دادند (IV).

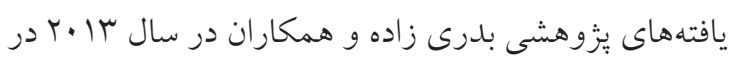

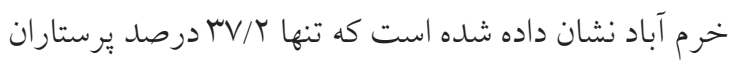

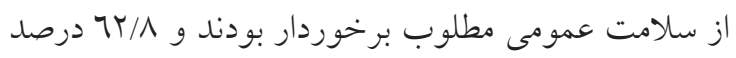

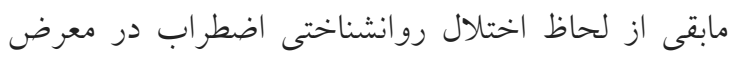

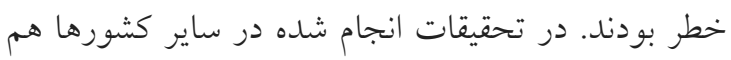

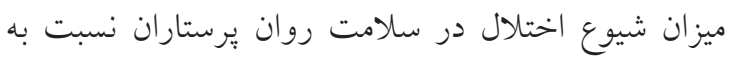
ساير اقشار جامعه بالاتر خزارش شده است، به خونهاى كه

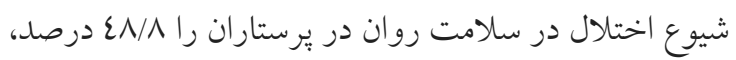

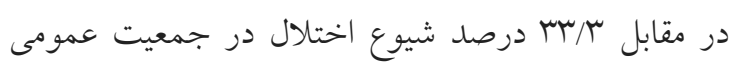

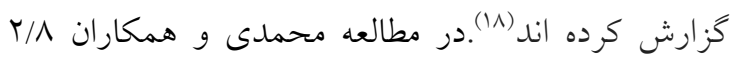

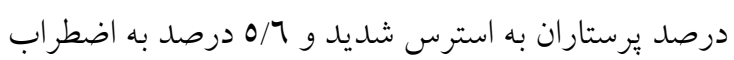
شديد مبتلا بودند (19). با توجه به اهميت موضوع و وجود مشكلات در دو زمينا نودينه

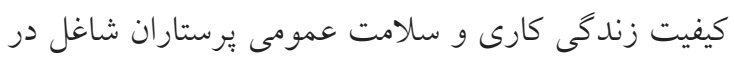

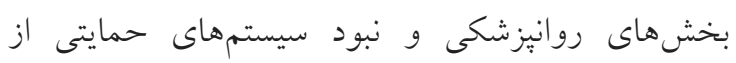
يرستاران بخش هاى روانيزشكى و در دسترس نبودن نتايج

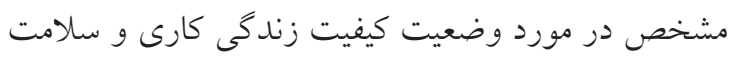

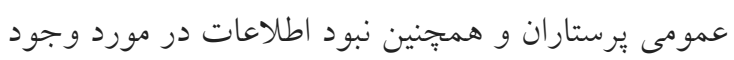

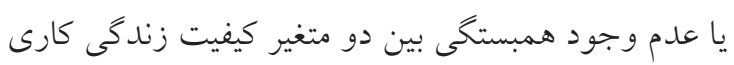

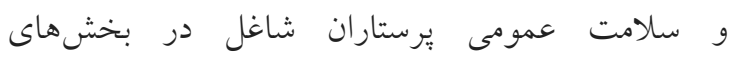

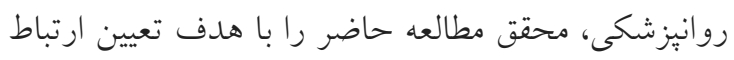

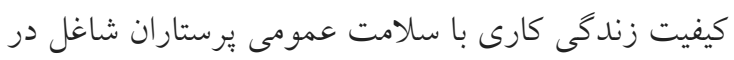

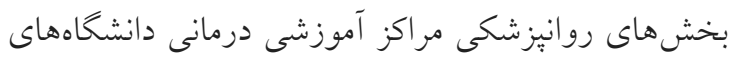

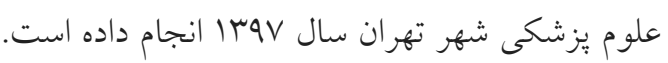

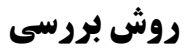

اين مطالعه توصيفى همبستخى از مرداد تا اسفند $9 V$ انجام

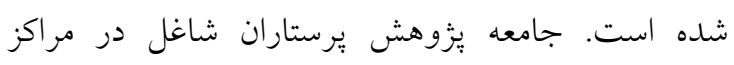

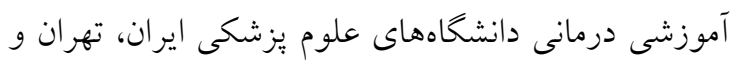

يرستاران در بخشهاى روانيزشكى در معرض انتظارات و

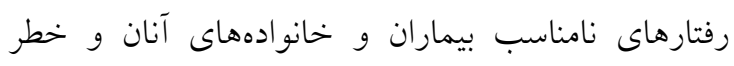

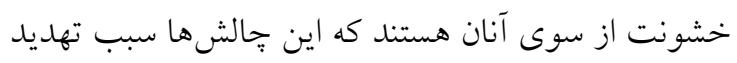

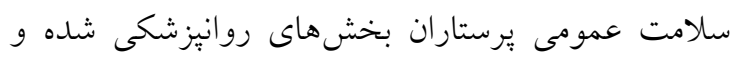

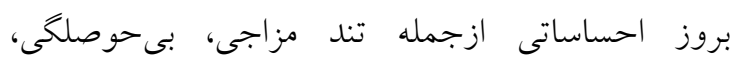
خستخى، خشم و فقدان همدردى نسبت به بيماران و كناره كيرى روانى و فيزيكى از بيمار را به همراه دارد"(11).

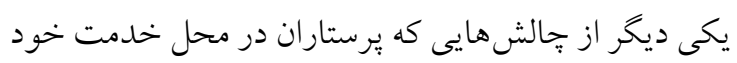

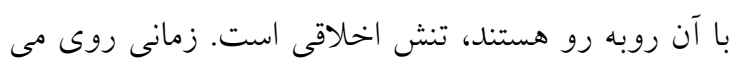

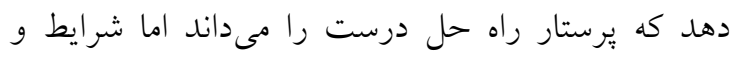

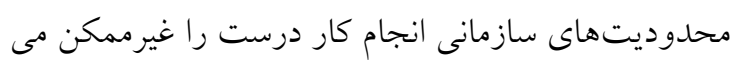

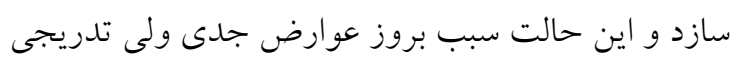
براى يرستاران خواهد شد. در بيشتر مواقع يرستاران

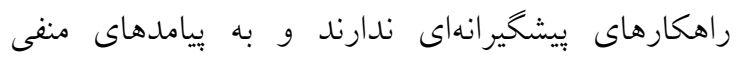

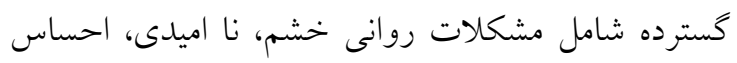

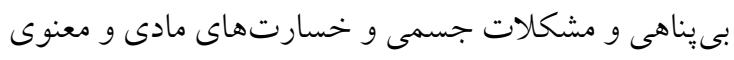

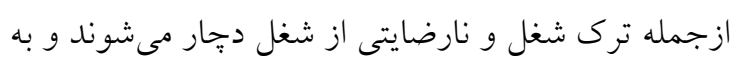

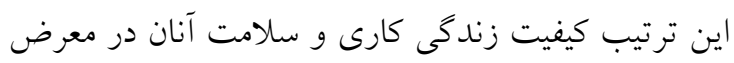
تهلديد قرار مى كيرد (Ir). در دو زمينه كيفيت زندگى كارى و سلامت عمومى مئى يرستاران مطالعاتى انجام شده است كه تعدادى از مطالعات

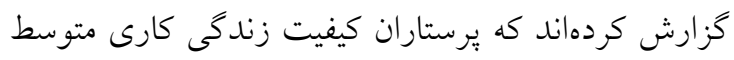

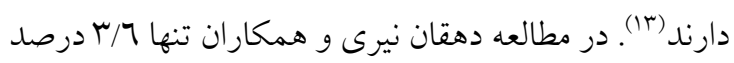

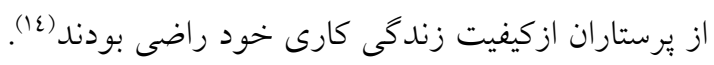

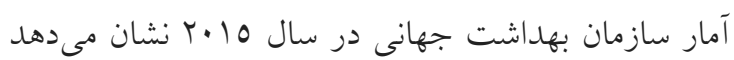
درصد نارضايتى از كيفيت زندگى كارى در همهى ابعاد آن،

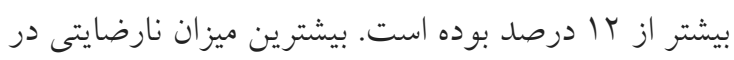

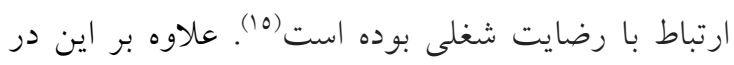

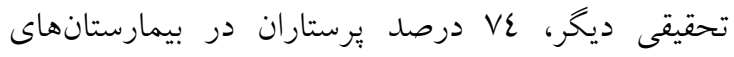

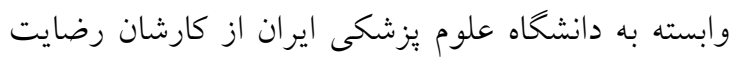

نداشتند (17). نتايج مطالعهى كيفيت زندكى كارى برستار ان دانشگاه علوم

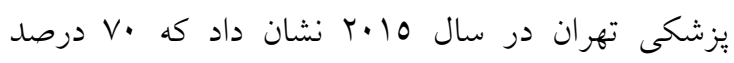
برستاران از كيفيت زندكى كارى خود راضى نيستند و از درن 
كه شامل ^r سئو ال در جهار زير مقياس شامل GHQ-28 علائم جسمى، اضطراب و بىخوابى، اختلال كاركرد

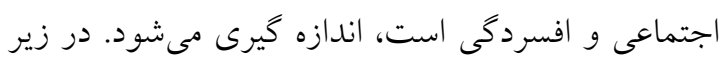
مقياس علائم جسمى، سلامت و علائم جسمى كه فرد از

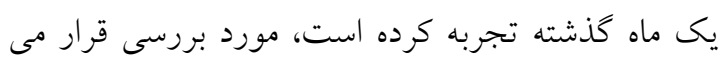
كيرد. در زير مقياس اضطراب و بـىخوابى، علائم و نشانه

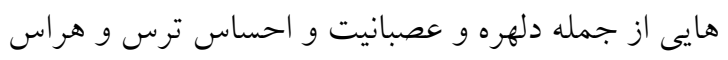

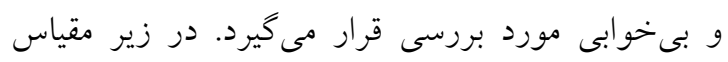

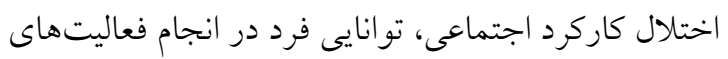

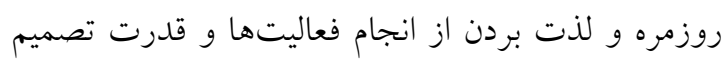

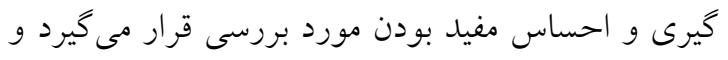

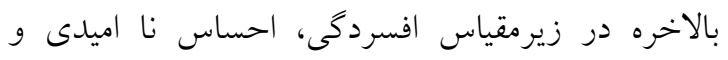

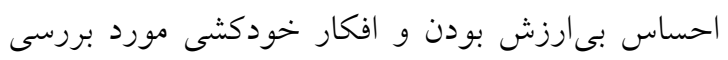

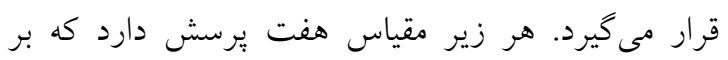

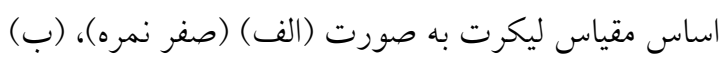

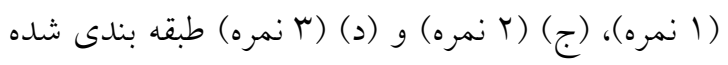

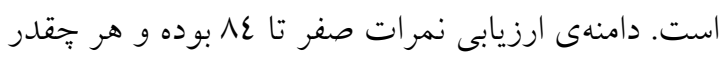

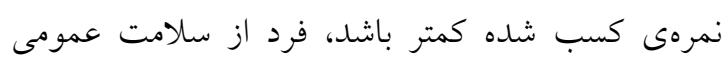
بالاترى برخوردار است.

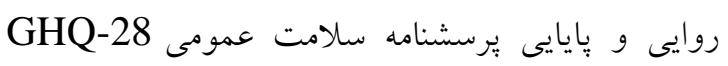

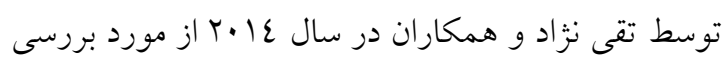

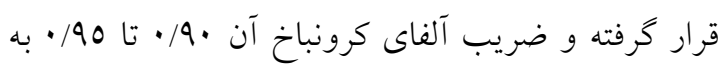

دست آمده است.

برسشنامه Quality of Work Life توسط Brooks و Anderson براى اندازهگيرى كيفيت زندگى كارى در

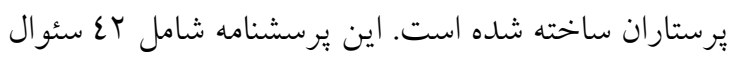

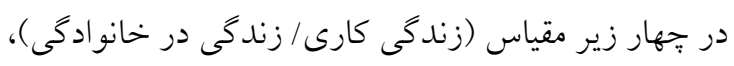

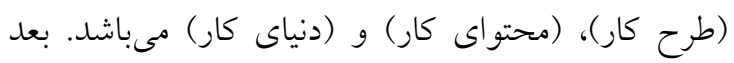

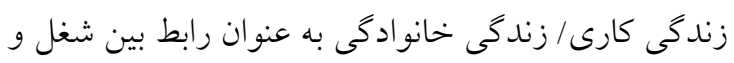

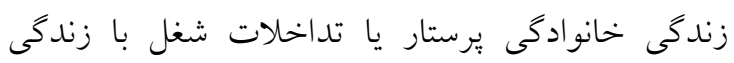

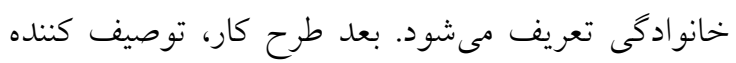

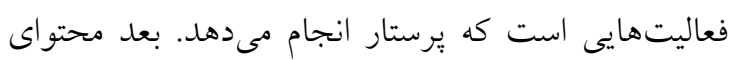

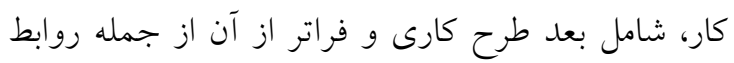
بين همكاران در محيط كار و اثرات محيط كار بر سيستم
شهيد بهشتى در تهران بوده است. حجم نمونه مورد نياز

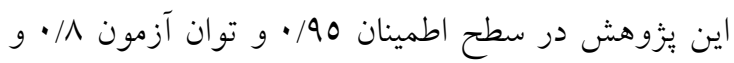

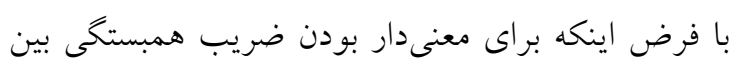

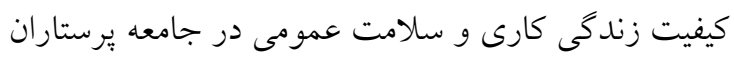

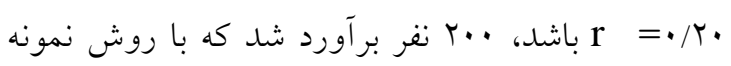
كيرى طبقهاى با تخصيص نسبتى از مراكز مربوطه انتخاب شده است. پس از گرفتن مجوز از كميته اخلاق دانشعاه علوم يزشكى

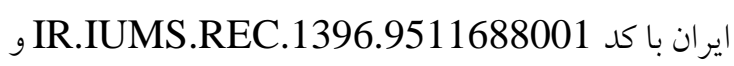

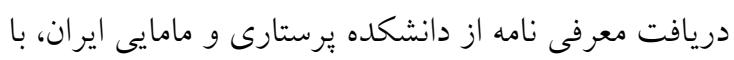
همكارى و راهنمايى سريرستاران بخشها، ليستى كامل از

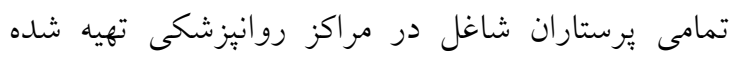

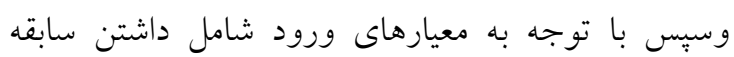

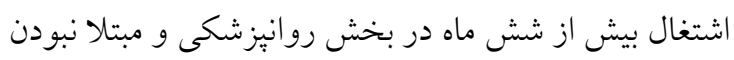
به اختلالات روانى تشخيص داده شده، شركت كنند أنان

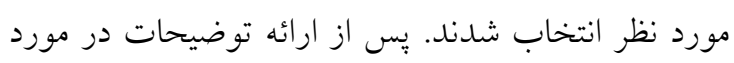

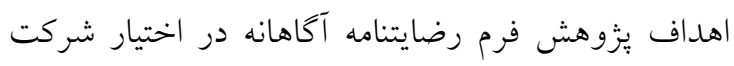

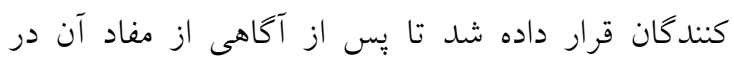
صورت تمايل نسبت به امضاى آن اقدام نموده و به مطالعه آنه

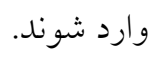

ابزارهاى جمع آورى دادهها

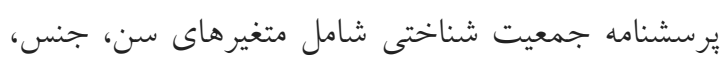

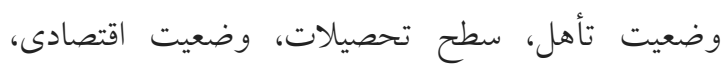

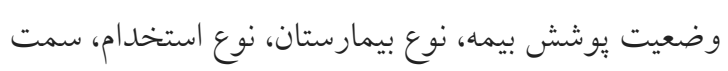

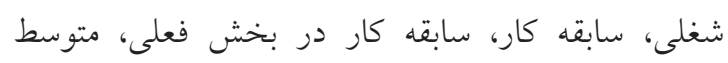

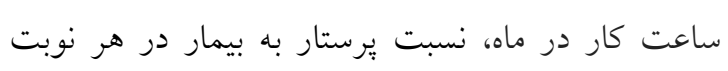

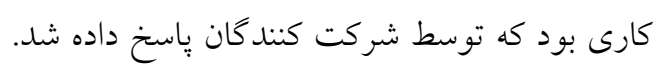

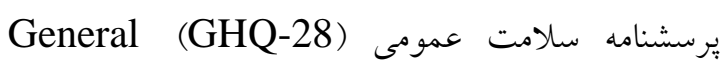
Health Questionnaire 19V1 توسط Hiller و ساخته شده است. به عنوان ابزار غربالكرى براى تشخيص كسانى كه احتمالا

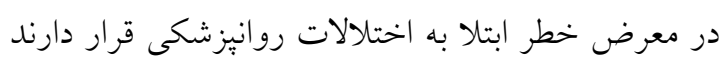

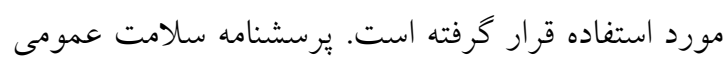


متغير هاى ســالامت عمومى و كيفيت ز ندكى كارى از

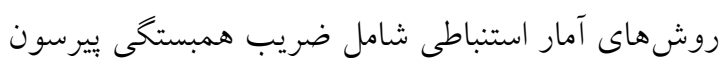

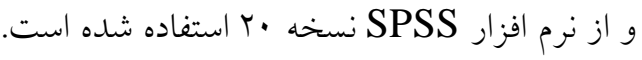

\section{يافتهها}

ميانخين نمره كيفيت زندكى كارى كسب شده يرستاران

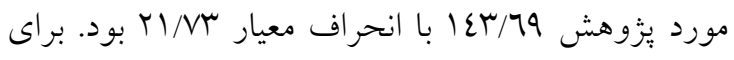
بررسى آنكه كدام يك از حيطهها بالاترين و وهايينترين

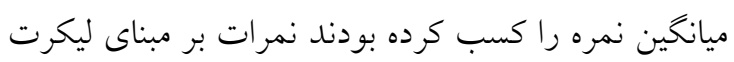
ا تا 7 محاسبه شد. ملاحظه مىشود كه بالاترين و ويايين

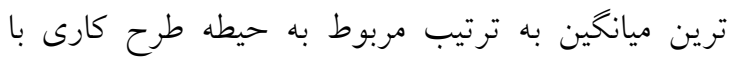

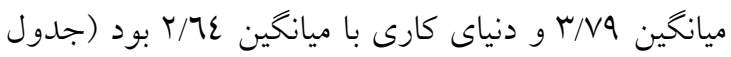

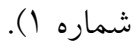

هاى برستار و بيمار است و بعد دنياى كار شامل تأثيرات وسيع اجتماعى و تغييرات در عملكرد يرستارى است. نمره

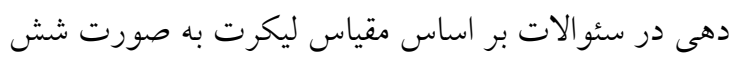

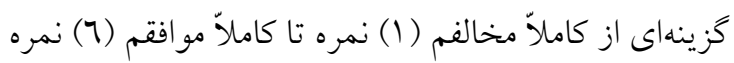

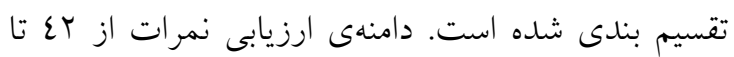
كم rOr كيفيت زندگى كارى بالاتر است.

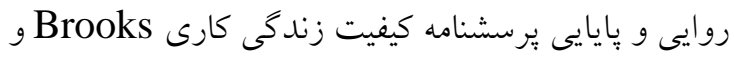

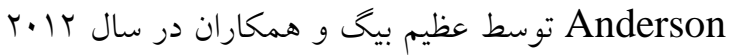

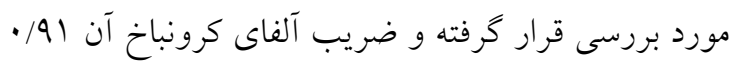
به دست آمده است. براى توصسيف دادهها از روشهاى آمار توصسيفى شـامل

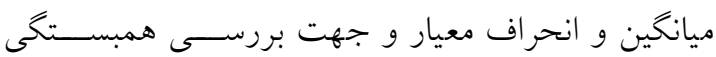

جدول شماره (: توزيع فراوانى شاخص هاى عددى كيفيت زندگى كارى ير ستاران شاغل در بخش هاى روانيزشكى

\begin{tabular}{|c|c|c|c|c|c|c|c|c|}
\hline \multicolumn{4}{|c|}{ مبناى ا تا 7} & \multirow[t]{2}{*}{ انحر اف معيار } & \multirow[t]{2}{*}{ 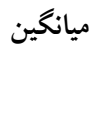 } & \multirow[t]{2}{*}{ 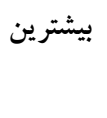 } & \multirow[t]{2}{*}{ 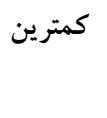 } & \multirow[t]{2}{*}{ كيفيت زندگى كارى و حيطههاى آن } \\
\hline انحر اف معيار & ميانخين & بيشترين & 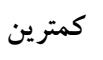 & & & & & \\
\hline$\cdot / \mathrm{NA}$ & $r / \mu r$ & $0 / 1 \mathrm{~V}$ & 1/OV & $0 / \varepsilon V$ & $r r / 0 \varepsilon$ & $r \bar{r} / \mathrm{V}$ & 11 & زندگى كارى/ خانو ادگى (V-EY) \\
\hline$\cdot / 71$ & r/va & $0 / 1$ & r & $7 / 17$ & rV/at & 01 & r. & طرح كارى (•7-•() \\
\hline$\cdot 101$ & $r / \varepsilon \varepsilon$ & $\varepsilon / v \varepsilon$ & $r / r$ & $11 / 7 \pi$ & $71 / 10$ & $9 \varepsilon / V \varepsilon$ & $\varepsilon \varepsilon$ & 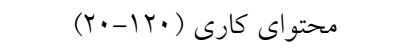 \\
\hline.$/ 99$ & $r / \nearrow \varepsilon$ & $0 / 7$ & 1 & $\varepsilon / 97$ & $\mid r / r \varepsilon$ & 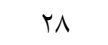 & 0 & دنياى كارى (·r-0) \\
\hline .101 & $r / \varepsilon 1$ & $\varepsilon /\rceil \Lambda$ & $r / r q$ & $r / N r$ & $1 \varepsilon r / 7 q$ & $197 / \% 0$ & 97 & كيفيت زندگى كارى (YY-IYT) \\
\hline
\end{tabular}

درصد از يرستاران مورد يزوهش در سلامت عمومى هيج مشكلى نداشتند و هيجكدام مشكلات در سطح شديد

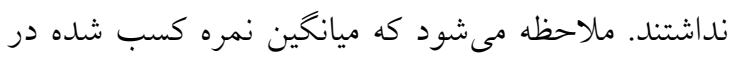

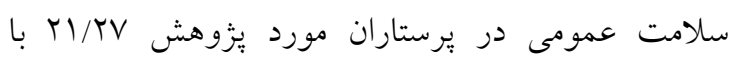

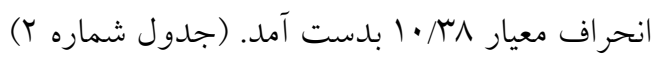

سلامت عمومى بيش از نيمى از يرستاران مورد يزوهش در

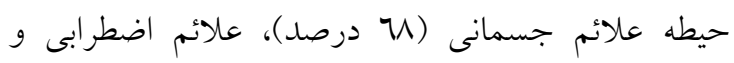

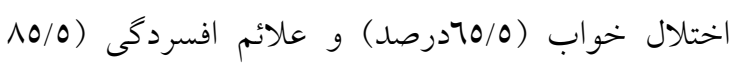
درصد) بدون مشكل بوده است. كاركرد اجتماعى 10 درصد از يرستاران داراى مشكل در سطح خفيف بود بود.

جدول شماره ז: فراوانى و شاخصهاى عددى سلامت عمومى و زيرمقياسهاى آن در يرستاران شاغل در بخشهاى روانيزشكى دمانى

\begin{tabular}{|c|c|c|c|c|}
\hline انحراف معيار \ ميانگين & درصد & فراوانى & \multicolumn{2}{|c|}{ سلامت عمومى و زير مقياسهاى آن } \\
\hline $0 / r \varepsilon \pm r / \varepsilon 0$ & u & $1 \% 7$ & هيج & \\
\hline \multirow[t]{3}{*}{$\cdot-1 \mathrm{IV}$} & ro & 0. & خفيف & علائم جسمانى \\
\hline & 7 & ir & متوسط & \\
\hline & 1 & $r$ & شديد & \\
\hline
\end{tabular}




\begin{tabular}{|c|c|c|c|c|}
\hline $0 / \mu\urcorner \pm \varepsilon / \cdot r$ & $70 / 0$ & $|r|$ & هيج & \\
\hline \multirow[t]{3}{*}{$\cdot-11$} & ro/o & 01 & خفيف & علائم اضطر ابى و اختلال خواب \\
\hline & $\mathrm{V} / 0$ & 10 & متوسط & \\
\hline & $1 / 0$ & r & 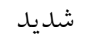 & \\
\hline$V / T V \pm T / 1 T$ & M1/0 & $7 \pi$ & هيج & \\
\hline \multirow[t]{2}{*}{$1-1 \varepsilon$} & 70 & 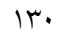 & خفيف & كاركرد اجتماعى \\
\hline & $r / 0$ & $\checkmark$ & متوسط & \\
\hline$r / r q \pm r / r$ & $10 / 0$ & $|V|$ & هيج & \\
\hline \multirow[t]{2}{*}{$\cdot-17$} & ir & $r \varepsilon$ & خفيف & علائم افسردگى \\
\hline & $r / 0$ & 0 & متوسط & \\
\hline$r I / r V \pm 1 \cdot / r \Lambda$ & $7 \varepsilon$ & $\mid r \wedge$ & هيج & \\
\hline \multirow[t]{2}{*}{$\cdot-O V$} & $r$. & 7. & خفيف & سلامت عمومى \\
\hline & 7 & ir & متوسط & \\
\hline
\end{tabular}

بايينترين ميانخين به ترتيب مربوط به بعد كاركرد اجتماعى

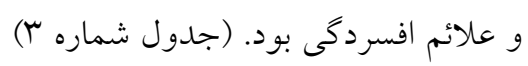

ميانخين نمره سلامت عمومى كسب شده يرستاران مورد

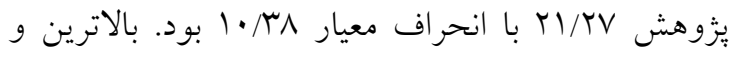

جدول شماره س: همبستكى كيفيت زندَّى كاريو حيطههاى آن با سلامت عمومى و حيطههاى آن در يرستاران شاغل در بخشهاى روانيزشكى

\begin{tabular}{|c|c|c|c|c|c|}
\hline \multicolumn{5}{|c|}{ سلامت عمومى و حيطه هاى آن } & \multirow{2}{*}{ كيفيت زندگى كارى و } \\
\hline سلامت عمومى & علائم افسردگى & كاركرد اجتماعى & علائم اضطر ابى و اختلال خواب & علائم جسمانى & \\
\hline$r=-\cdot / r \circ r$ & $r=-\cdot / r \cdot V$ & $r=\cdot 1 \cdot 70$ & $r=-\cdot / r \wedge r$ & $r=-\cdot / r \wedge \uparrow$ & زندكى كارى/ خانوادگى \\
\hline $\mathrm{P}<\cdot / \cdot \cdot 1$ & $\mathrm{P}=\cdot / \cdot r$ & $\mathrm{P}=\cdot / \Gamma \circ \Lambda$ & $\mathrm{P}<\bullet / \cdot \cdot 1$ & $\mathrm{P}<\bullet / \cdots 1$ & \\
\hline$r=\cdot / 1 \cdot 9$ & $r=-\cdot / \cdot 7$ & $\mathrm{r}=\cdot / r Y q$ & $r=\cdot / 11 \varepsilon$ & $r=\cdot / 1 \cdot r$ & طرح كارى \\
\hline $\mathrm{P}=\cdot / 1 r_{0}$ & $\mathrm{P}=\cdot / \sim 90$ & $\mathrm{P}=\cdot / \cdot \cdot 1$ & $P=\cdot / 1 \cdot 9$ & $\mathrm{P}=\cdot / / \varepsilon \wedge$ & \\
\hline$r=-\cdot / 1 \cdot 7$ & $r=-\cdot / 11 \wedge$ & $r=\cdot / \cdot 7 r$ & $r=-\bullet / 1 r q$ & $r=-\cdot / 1 \cdot \varepsilon$ & محتواى كارى \\
\hline $\mathrm{P}=\cdot / 1 \mathrm{ro}$ & $\mathrm{P}=\cdot / \cdot 90$ & $\mathrm{P}=\cdot \pi \vee q$ & $\mathrm{P}=\cdot / \cdot 79$ & $\mathrm{P}=\cdot / 1 \varepsilon r$ & \\
\hline$r=-\cdot / / \varepsilon \wedge$ & $\mathrm{r}=-\cdot / .01$ & $\mathrm{r}=/ \cdot \cdot \varepsilon$ & $\mathrm{r}=-\cdot / r \cdot 7$ & $r=-\cdot / 17 \varepsilon$ & دنياى كارى \\
\hline$P=\cdot / \cdot r V$ & $\mathrm{P}=\cdot / \varepsilon \vee \varepsilon$ & $\mathrm{P}=\cdot / 90 \wedge$ & $\mathrm{P}=\cdot / \cdot r$ & $\mathrm{P}=\cdot / \cdot r$ & \\
\hline $\mathrm{r}=-\cdot / 1 \mathrm{ro}$ & $\mathrm{r}=-\cdot / 1 \varepsilon 0$ & $r=. / 110$ & $\mathrm{r}=-\cdot / 10 \mathrm{~V}$ & $r=-\cdot / 1 r q$ & كيفيت زندگى كارى \\
\hline $\mathrm{P}=\cdot / \cdot \mathrm{VV}$ & $\mathrm{P}=\cdot / \cdot \varepsilon 1$ & $\mathrm{P}=\cdot / 1 \cdot 0$ & $\mathrm{P}=\cdot / \cdot r\urcorner$ & $\mathrm{P}=. / .01$ & \\
\hline
\end{tabular}

خانوادگى نمره سامت عمومى در اين حيطهها كاهش مى يابد يعنى سلامت عمومى در اين حيطهها بهتر خواهد بود.

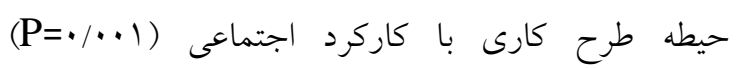
همبستخى معنى دار آمارى داشته كه اين همبستخى مثبت بود يعنى با افزايش نمره كيفيت زندكى در حيطه طرح

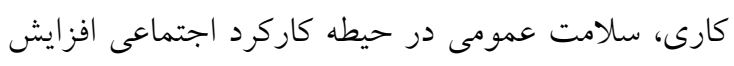

كيفيت زندگى كارى در حيطه زندگى كارى/ خانوادگى با سلامت عمومى در حيطههاى علائم جسمانى ( ( + (P) (P)، علائم اضطرابى و اختلال خواب (1) (P) (P) و علائم

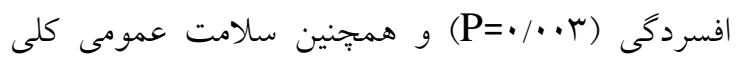
همبستخى معنى دار آمارى داشته كه اين همبستخى به آه صورت معكوس است يعنى با افزايش نمره زندكى كارى/ 
ازجمله جنس، تأهل، سابقه كار با حيطههاى سلامت عمومى و كيفيت زندگى كارى ارتباط معنىدار نداشت.

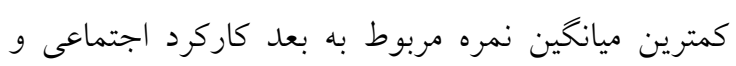
بالاترين ميانگين مربوط به بعد علائم اضطر بيى و اختلال

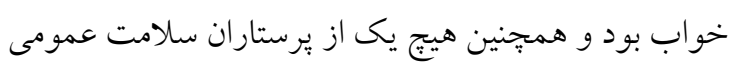

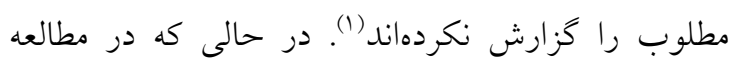

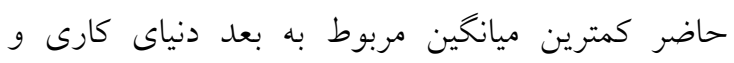

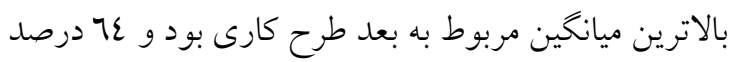

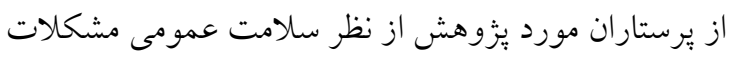
در سطح شديد نداشتند. وجود تفاوت در نتايج دو مطالعه مىتواند ناشى از تفاوت محيط يزّوهش، شرايط كارى و

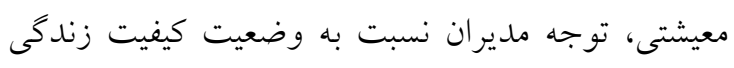

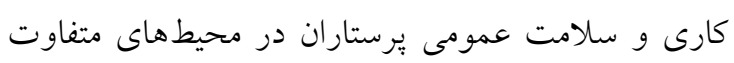

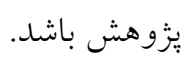

در مطالعهى Itzhaki و همكاران كه در مراكز روانيزشكى باتسى

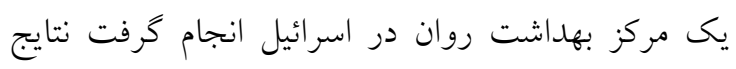
نشان داد كه كيفيت زندگى كارى با خشونت در محل كار

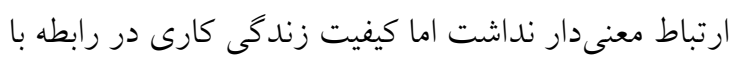
استرس شغلى و تجربه خشونت قبلى كاهش يافته است (9). در بخشهاى روانيزشكى به علت ارتباط كسترده با باني مددجويان و ماهيت بيمارى آنان احتمال خشونت عليه عليه

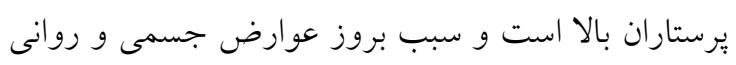

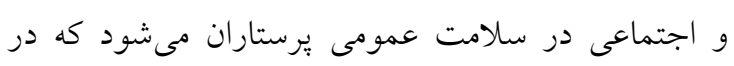
مطالعه حاضر برستاران در دو بعد علائم جسمى و علائم اضطرابى و اختلال خواب مشكلات در سطح شديد را

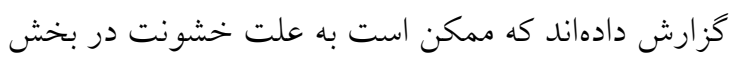
روانيزشكى و عدم وجود احساس امنيت باشد.

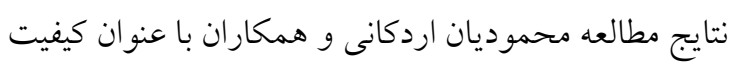

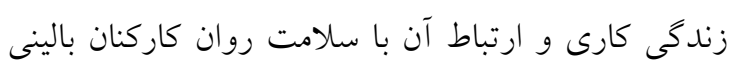

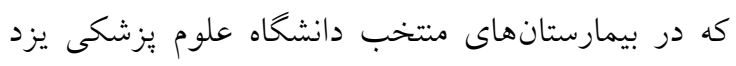

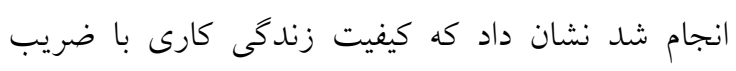

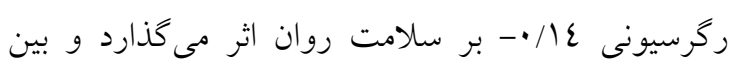

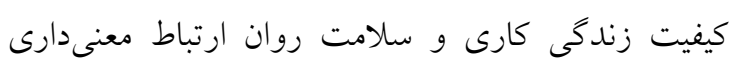
وجود داشته است (r.).
مى يابد يعنى وضعيت سلامت عمومى در اين حيطه بدتر دنياى كارى با سلامت عمومى در دو حيطه علائم جسمانى

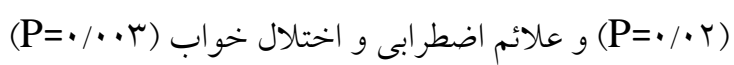

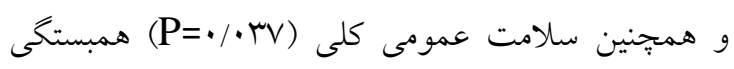

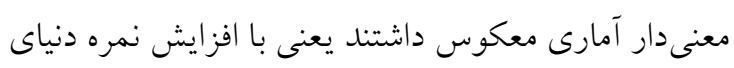
كارى نمره سلامت عمومى در اين حيطهها كاهش مى يابد يعنى سلامت عمومى در اين حيطهها بهتر خواهد بود.

\section{بحث و نتيجه تيرى}

مطالعه حاضر به منظور بررسى سطح كيجى كيفيت زندكى كارى

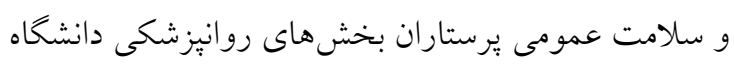
هاى علوم بزشكى شهر تهران و تعيين نحوهى ارتباط بين بندين

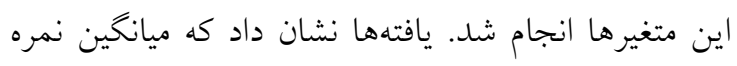

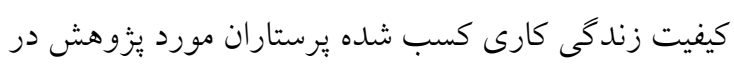

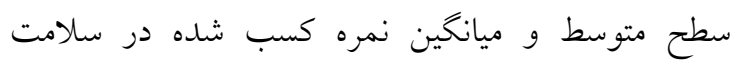
عمومى آنان در سطح خوب به دست آمد. كيفيت زندكى كارى به طور كلى با سلامت عمومى در دو حيطه علائم

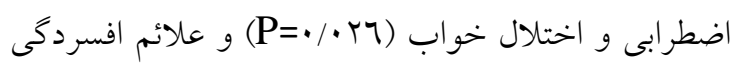

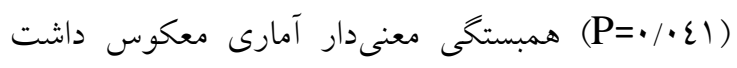

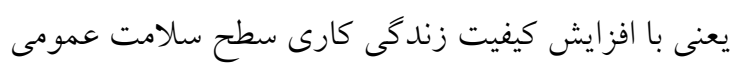
در دو بعد علائم اضطرابى و اختلال خواب و و علائم

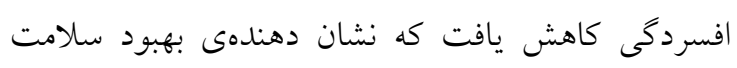
عمومى در دو بعد ذكر شده است. كيفيت زندكى كارى با بافي

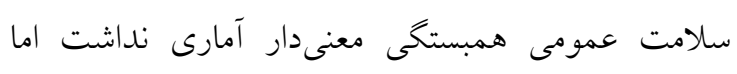

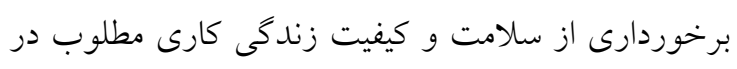
كاركنان بيمارستانها منجر به برنامهريزى بهتر و خلاقانه تر بردي

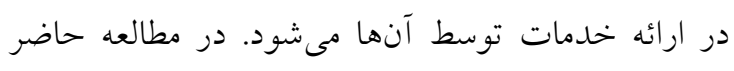

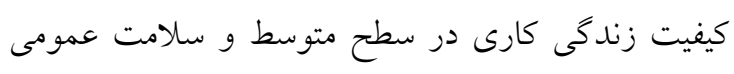
در سطح خوب اندازه كيرى شد، در مطالعهى نجفى و ونس

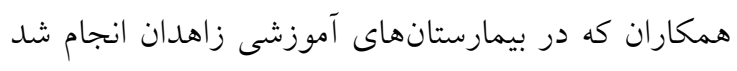
مشخص شده است كه بين متغيرهاى كيفيت زندكى كارى

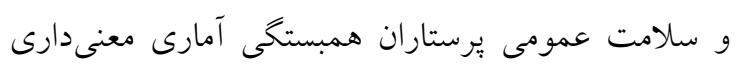
وجود نداشته است. همجنين متغيرهاى جمعيت شناختى 
در سال rا • r مطالعهاى با عنوان بررسى ارتباط بين كيفيت

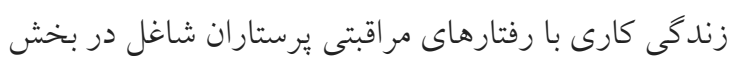

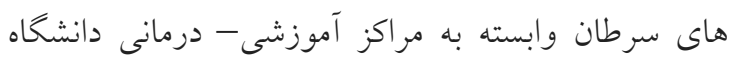

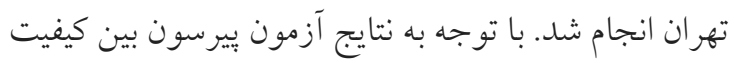

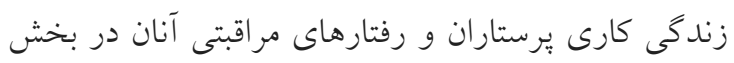

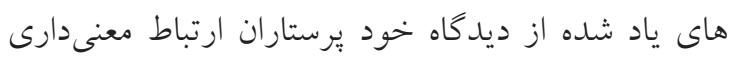

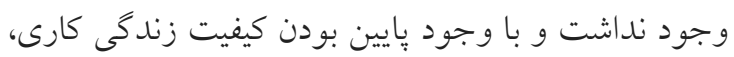
رفتارهاى مر اقبتى از سوى يرستاران در سطح مطلوب بار ارئه بائه

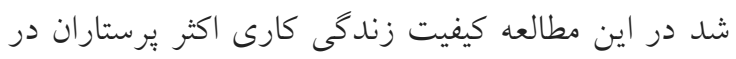

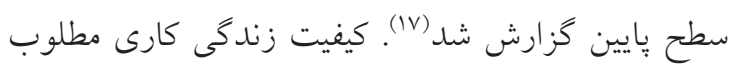
از عوامل اساسى توانمندسازى منابع انسانى مورد نياز سيستم مراقبت بهدانتى است، توجه بيشتر به ابعاد كيفيت زندكى كارى جهت حفظ و بقاى كاركنان بسيار حائز اهميت است. در مطالعه حاضر سطح كيفيت زندكى كارى متوسط كزارش شد كه ناشى از توجه بيشتر به ابعاد كيفيت

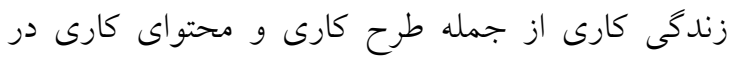

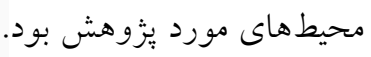
با توجه به يافتهاى اين مطالعه مىتوان اين كونه بيان

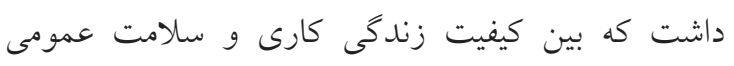

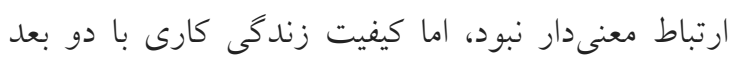

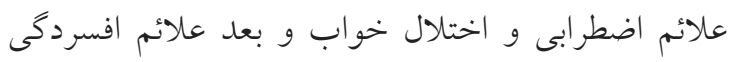

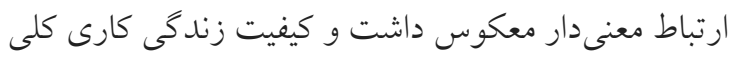

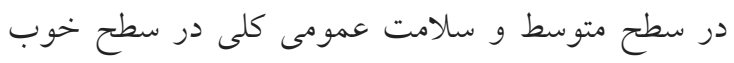

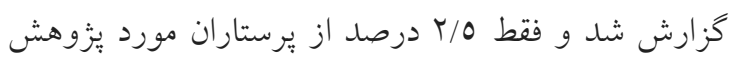

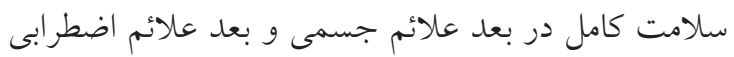

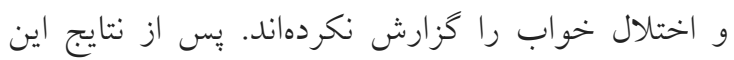

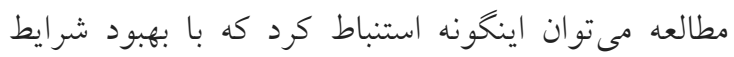
كيفيت زندگى كارى، سلامت عمومى در همه ابعاد در

$$
\text { سطح خوب برآورد خواهد شد. }
$$

با توجه به يافته هاى اين مطالعه كه نشان دهندورى سطح

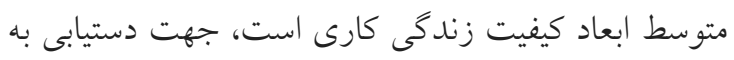

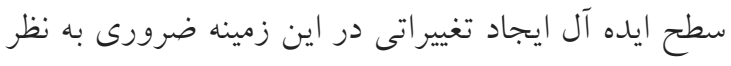

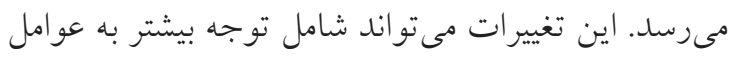

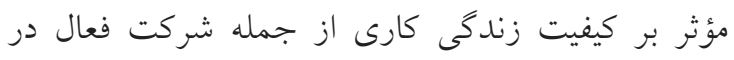

در مطالعهى González-Baltazar و همكاران كه در بخش مراقبت هاى اوليه يك مؤسسه بهداشت عمومى در

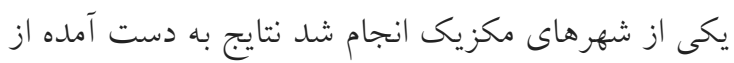

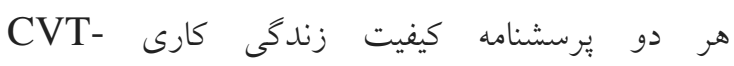
GOHISALO بررسى قرار كرفت و دريافتند كه بين مواردى كه كيفيت

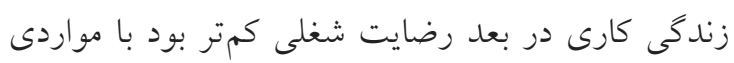
كه سلامت روانى مطلوب نداشتند ارتباط معنىدار وجود داشت (10). در مطالعه محمدى و همكاران با عنوان ارتباط مشكلات

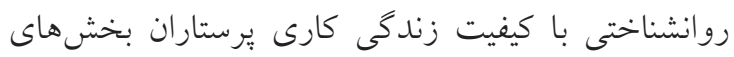

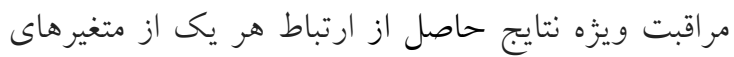

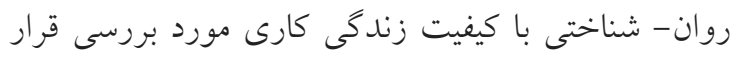

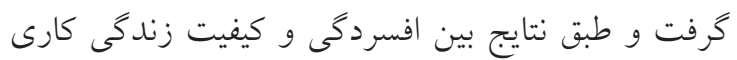
ارتباط معنى دار مشاهده نشد ولى بين اضطراب و كيفيت زندگى كارى ارتباط معنى دار مشاهده شد (19).

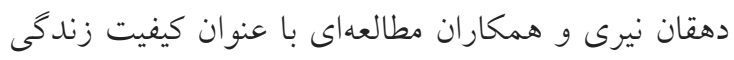

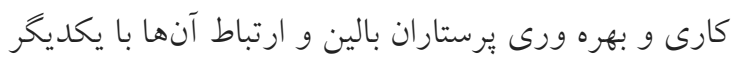

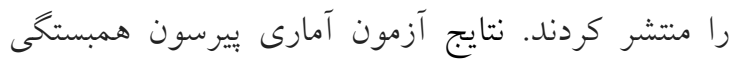

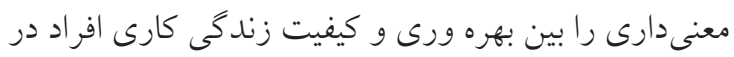
اين مطالعه نشان داد (ع). نتايج مطالعات فوق با نتايج مطالعه حا ضر متفاوت ا ست. در همه مطالعات فوق بين متغيرهاى اصسلى مطالعه ارتباط معنى دار وجود داشته است در حالى كه در اين مطالعه بين كيفيت زندكى كارى و ســالامت عمومى ارتباط معنى دار

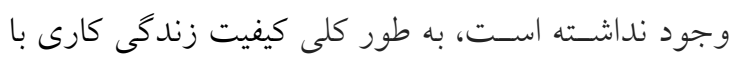
سـلامت عمومى در دو حيطه علائم اضـطر ابى و اختلال

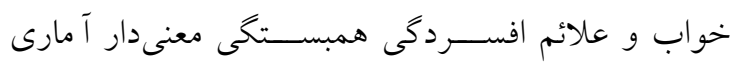
معكوس دا شت يعنى با افزايش كيفيت زندكى كارى نمره سـالامت عمومى در اين حيطهها كاهش مى يابد كه نشـان

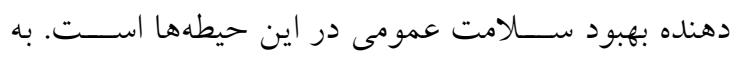

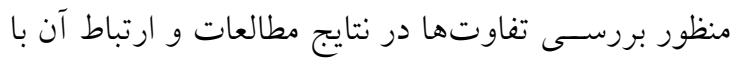

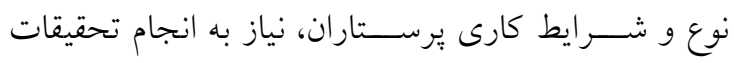
بيشترى است. 


$$
\begin{aligned}
& \text { از محدوديتهاى يُزوهش مىتوان به روش خود كزارشى آنى } \\
& \text { جمع آورى اطلاعات اشاره كرد كه ممكن است نتايج يافته }
\end{aligned}
$$

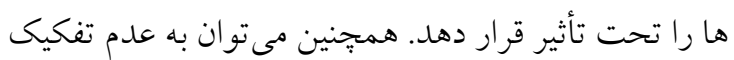

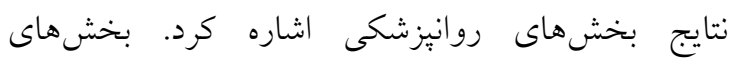

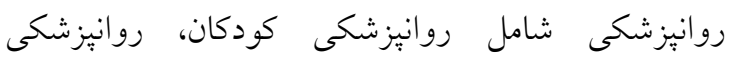

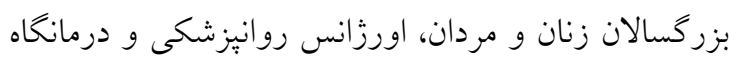

$$
\begin{aligned}
& \text { روانيزشكى است كه هر يك عوامل استرس زاى خود را } \\
& \text { دارا دارند. ييشنهاد مىشود يزوهشى جهت تعيين شرايط } \\
& \text { محيط كارى برستاران شاغل در بخشهاى مختلف و ارتباط }
\end{aligned}
$$

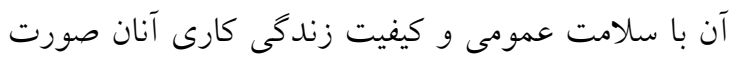

$$
\begin{aligned}
& \text { كيرد، تا عواملى كه در محيط سلامت عمومى و كيفيت }
\end{aligned}
$$

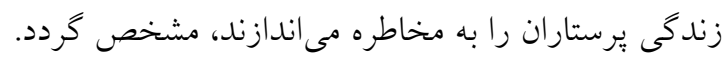$$
\text { تعارض منافع:هيجگگ نه تعارض منافع از سوى نويسند گان }
$$

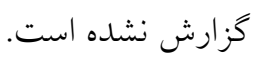

\section{تقدير و تشكر}

اين مطالعه مربوط به طرح يزوهشى مصوب دانشك دانحاه علوم

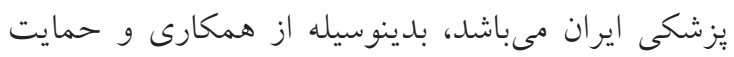

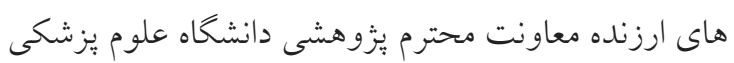

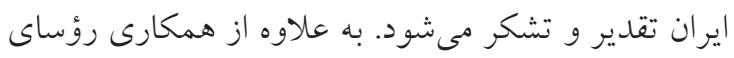

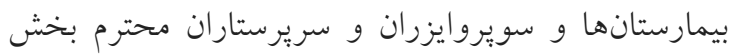

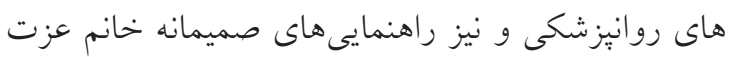

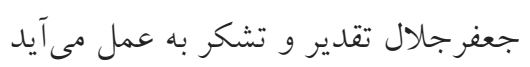

$$
\begin{aligned}
& \text { تصميم گيرى مربوط به مسائل درمانى، فراهم كردن اوقات }
\end{aligned}
$$

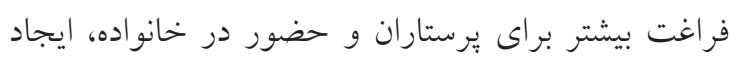

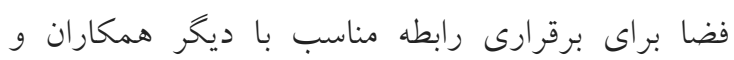

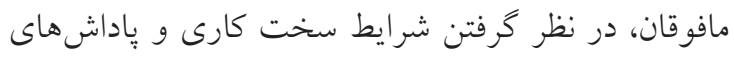

$$
\begin{aligned}
& \text { مالى و غيرمالى براى يرستاران توسط محققان، برنامه ريزان }
\end{aligned}
$$

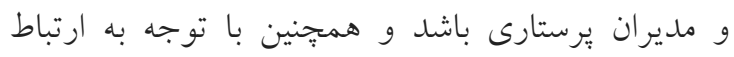

$$
\begin{aligned}
& \text { معكوس و معنى دار كيفيت زندكى كارى با دو بعد علائم } \\
& \text { اضطرابى و اختلالات خواب و بعد افسردگى از ابعاد } \\
& \text { سلامت عمومى، ارائه راهكارهايى از جمله ايجاد شبكه } \\
& \text { حمايتى - اجتماعى، بهبود امكانات رفاهى و تفريحى، انجام }
\end{aligned}
$$

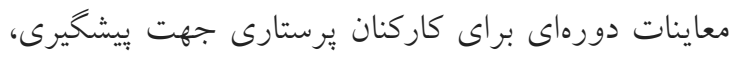

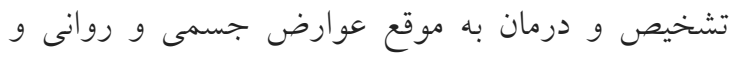

$$
\begin{aligned}
& \text { اجتماعى بيشنهاد مى شود. } \\
& \text { با توجه به شرايط بخشهاى روانيزشكى بسيارى از }
\end{aligned}
$$

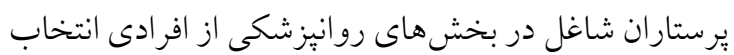

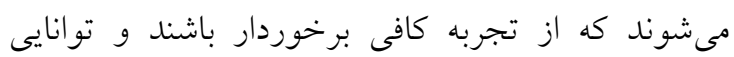

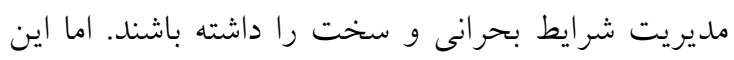

$$
\begin{aligned}
& \text { مسئله سبب به مخاطره افتادن سلامت عمومى اين دسته از } \\
& \text { برستاران خواهد شد زيرا قسمت عظيمى از انرزى روزانه } \\
& \text { اين افراد صرف كارهاى مديريتى و ارتباطى و مشاورهاى }
\end{aligned}
$$

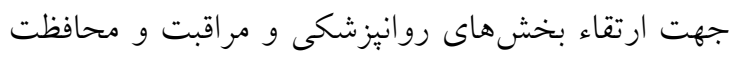

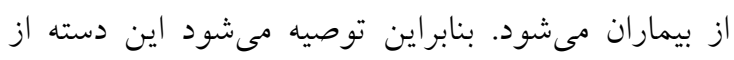

$$
\begin{aligned}
& \text { يرستاران مورد توجه ويزهاى قرار كيرند. }
\end{aligned}
$$

\section{References}

1. Najafi F, Kermansaravi F, Gangoozehi E. The Relationship between General Health and Quality of Work Life of Nurses Working in Zahedan Teaching Hospitals. Iranian Journal of Rehabilitation Research in Nursing. 2018;4(2):53-9. [Persian]

2. Khammarnia M, Shahsavani F, Shahrakipour M, Barfar E. Relationship Between Knowledge Management and Quality of Working Life in Nursing Staff of Zahedan Teaching Hospitals, 2014. Health Scope. 2015 Mar 2;4(1). [Persian]

3. Ramesh N, Nisha C, Josephine AM, Thomas S, Joseph B. A study on quality of work life among nurses in a medical college hospital in Bangalore. Nat J Comm Med. 2013;4(3):471-4.

4. Thakre SB, Thakre SS, Thakre SN. Quality of work life of nurses working at tertiary health care institution: a cross sectional study. Int J Community Med Public Health. 2017;4(5):1627-36.

5. Mudiraj D. A Study on Mental Health and Quality of Work Life among teachers Working in Corporate Schools. International Journal of Indian Psychology. 2017;4(2):96-102. 
6. Picco L, Yuan Q, Vaingankar JA, Chang S, Abdin E, Chua HC, Chong SA, Subramaniam M. Positive mental health among health professionals working at a psychiatric hospital. PloS one. 2017;12(6):e0178359.

7. Eslamian J, Akbarpoor AA, Hoseini SA. Quality of work life and its association with workplace violence of the nurses in emergency departments. Iran J Nurs Midwifery Res. 2015; 20(1): 56-62. [Persian]

8. Parvin N, Vardanjani R. Problems of the Nurses Working in Psychiatric Wards of Sina and Hajar Hospital in Dealing with Aggressive Patients in Shahrekord. jgbfnm. 2014;11(1):24-31. [Persian]

9. Itzhaki M, Bluvstein I, Peles Bortz A, Kostistky H, Bar Noy D, Filshtinsky V, Theilla M. Mental health nurse's exposure to workplace violence leads to job stress, which leads to reduced professional quality of life. Frontiers in psychiatry. 2018;9:59.

10. Maghsoodi S, Hesabi M, Monfared A. General health and related factors in employed nurses in Medical-Educational Centers in Rasht. Journal of Holistic Nursing And Midwifery. 2015;25(1):6372. [Persian]

11. Ramezani T, Fasihi T, Mangali M. Nurses experiences of occupational aggression in the psychiatric wards: Phenomenology approach. Journal of fundamentals of mental health. 2012;13(4):314-27. [Persian]

12. Mahdavi Fashtami S, Mohammadeh zadeh Zarankesh S, Esmaeilpour Bandboni M. Moral distress among emergency department nurses: frequency, intensity, effect. Medical Science Journal of Islamic Azad Univesity-Tehran Medical Branch. 2016;26(4):248-55. [Persian]

13. Moradi T, Maghaminejad F, Azizi-Fini I. Quality of working life of nurses and its related factors. Nursing and midwifery studies. 2014 Jun;3(2). [Persian]

14. Dehghannyieri N, Salehi T, Asadinoghabi AA. Assessing the quality of work life, productivity of nurses and their relationship. Iranian Journal of Nursing Research. 2008;3(9):27-37. [Persian]

15. González-Baltazar R, Hidalgo-Santacruz G, León-Cortés SG, Contreras-Estrada MI, AldreteRodríguez MG, Hidalgo-González BJ, Barrera-Vega JA. Quality of work life and mental health in primary care physicians. Procedia Manufacturing. 2015;3:4935-40.

16. Dehaghi ZH, Sheikhtaheri A. Quality of work life and job satisfaction of nursing managers. Iranian journal of public health. $2014 ; 43(4): 537-8$. [Persian]

17. Hossein oghli gort tapeh S, Sedalshohadaee M. Relationship between qualityof work life and nurses caring behaviors in cancer wards of hospitals affiliated to Tehran University of Medical Sciences,3102. 2013.[Persian]

18. Badrizadeh A, Farhadi A, Tarrahi MJ, Saki M, Beiranvand G. Mental health status of the nurses working in Khorramabad state hospitals. Yafte. 2013;15(3):62-9. [Persian]

19. Mohammadi A, Sarhanggi F, Ebadi A, Daneshmandi M, Reiisifar A, Amiri F, Hajamini ZA. Relationship between psychological problems and quality of work life of Intensive Care Unit Nurses. Iran J Crit Care Nur. 2011;43:135-40. [Persian]

20. Mahmoodian Ardakani Z, Bahrami MA, Montazeralfaraj R, Fallahzadeh H, Mohammadzadeh M. Relationship between Mental Health and Quality of Working Life among Clinical Staff of Selected Hospitals of Medical Sciences, Yazd. Management Strategies in Health System. 2017;1(2):11927. [Persian] 